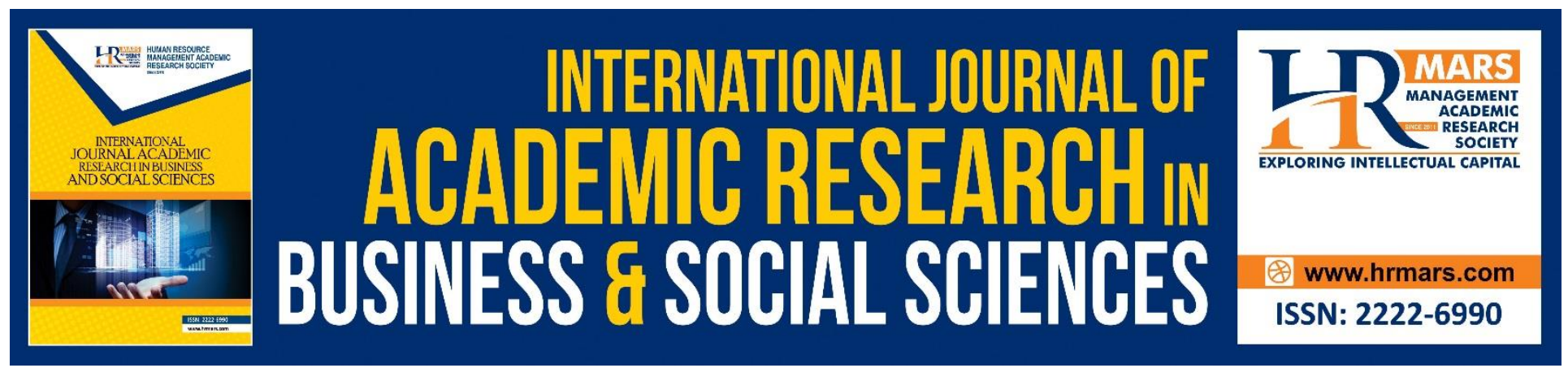

\title{
School-Based Management (SBM) Practices in Malaysia: A Systematic Literature Review
}

Anniliza Mohd Isa, Al-Amin Mydin, Abdul Ghani Kanesan Abdullah

To Link this Article: http://dx.doi.org/10.6007/IJARBSS/v10-i9/7870

DOI:10.6007/IJARBSS/v10-i9/7870

Received: 11 June 2020, Revised: 14 July 2020, Accepted: 15 August 2020

Published Online: 27 September 2020

In-Text Citation: (Isa, Mydin, \& Abdullah, 2020)

To Cite this Article: Isa, A. M., Mydin, A-A., \& Abdullah, A. G. K. (2020). School-Based Management (SBM)

Practices in Malaysia: A Systematic Literature Review. International Journal of Academic Research in Business and Social Sciences. 10(9), 822-838.

Copyright: (C) 2020 The Author(s)

Published by Human Resource Management Academic Research Society (www.hrmars.com)

This article is published under the Creative Commons Attribution (CC BY 4.0) license. Anyone may reproduce, distribute, translate and create derivative works of this article (for both commercial and non-commercial purposes), subject to full attribution to the original publication and authors. The full terms of this license may be seen

at: http://creativecommons.org/licences/by/4.0/legalcode

\section{Vol. 10, No. 9, 2020, Pg. 822 - 838}

Full Terms \& Conditions of access and use can be found at http://hrmars.com/index.php/pages/detail/publication-ethics 


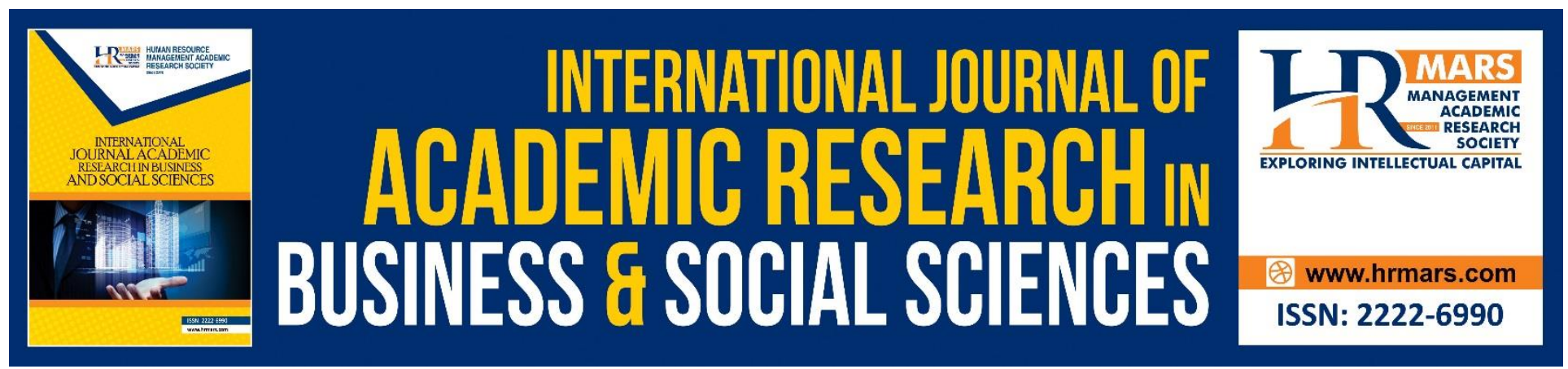

\title{
School-Based Management (SBM) Practices in Malaysia: A Systematic Literature Review
}

\author{
Anniliza Mohd Isa \\ School of Education Studies, Universiti Sains Malaysia, 11800, USM, Pulau Pinang, Malaysia \\ Email: anniliza@students.usm.my
}

Al-Amin Mydin

Universiti Sains Malaysia

Email: alamin@usm.my

\author{
Abdul Ghani Kanesan Abdullah \\ Universiti Sains Malaysia \\ Email: agk@usm.my
}

\begin{abstract}
School-Based Management (SBM) has been practised in Malaysia over the past two decades. However, SBM studies still found little attention among social science researchers in Malaysia. The details in the success of SBM implementation are still unclear. Thus, the researcher has emphasized the need to conduct a systematic review of existing studies to collect information on SBM in Malaysia. Four questions have been established in this review which are; (1) How SBM is implemented in Malaysia? (2) What is the classification level of SBM implementation strength in Malaysia? (3) To what extent are principals, teachers, parents and communities involved in SBM in Malaysia? and lastly, (4) What are the issues and challenges faced in schools related to SBM? The results of a decadelong literature review on SBM in Malaysia showed that SBM implementation in Malaysia was at a moderate level and had used a combination of two models, administrative-control SBM and professional-control SBM. Two critical issues identified from this review were on the role of the school leader and teacher competency. The researcher proposed the need for a standard instrument to evaluate SBM, highlighting the roles of district and state education officers in promoting empowerment among school leaders and teachers, as well as the involvement of the Parent-Teachers Association (PTA). Empowerment among school leaders encompasses leadership capacity while empowerment among teachers includes increasing motivation and professional guidance in various aspects such as pedagogy, professional development, accountability, and integrity.

Keywords: School-based Management, SBM, Autonomous School, Decision-making School.
\end{abstract}


INTERNATIONAL JOURNAL OF ACADEMIC RESEARCH IN BUSINESS AND SOCIAL SCIENCES Vol. 10, No. 9, 2020, E-ISSN: 2222-6990 @ 2020 HRMARS

\section{Introduction}

Authority decentralization to the school level has become a global education reform strategy and implemented to enhance the involvement of parents, students, teachers, officers, principals and stakeholders in local communities and organizations. Known as School-Based Management (SBM), this strategy is carried out to increase school independence, responsibility, and accountability (Bandur, 2012; Barrera-osorio, Fasih, Patrinos, \& Santibanez, 2009; Caldwell, 2005; Moradi, Hussin, \& Barzegar, 2012). Other terminologies used in addition to SBM are site-based management, sitebased decision making, school-based decision making, and shared decision making (Bandur, 2012; World Bank, 2013).

School-Based Management (SBM) serves as a new paradigm in education management; a package of educational reform in maintaining a balance of authority between the government and the school children, as well as an autonomous decision-making centre (Arar \& Nasra, 2018; Bandur, 2017; Tansiri \& Bong, 2018). In the education system, the level of decision making can be determined through the extent of autonomy by the school to be able to make decisions regarding curriculum, staff, and strategic planning processes (Alyami \& Floyd, 2019). Thus, School-Based Management can be defined as the responsibility of the school administrator (headmaster) to exercise his or her autonomy in making decisions on all matters regarding the school organization. The organization in a school includes administration, curriculum, co-curriculum, and student affairs, with involvement from the staff (teachers), clients (parents and students), and collaboration with local communities.

The ideology of decentralization of school-based education and management was first discussed in the 1970s and 1980s in developed countries, followed by developing countries (Barreraosorio et al., 2009; Caldwell, 2005; Varatharaj, 2015) in 2000s such as Indonesia in 2001 (Bandur, 2012) and the Philippines in 2006 (World Bank, 2013). The decentralized model implemented by each government is different but still focused on improving the autonomy of local government, district education offices, and schools (Barasa, 2014). Leithwood and Menzies (1998) classified SBM into four models which are administrative-control SBM, professional-control SBM, community-control SBM, and balanced-control SBM. The administrative-control SBM puts the authority only in the hands of the school leader, whereby he or she is entirely in charge of budget allocations in the school and the curriculum. On the contrary, the professional-control SBM gives the autonomy and decision-making power to teachers, by optimizing teachers' knowledge on the needs of the students at the classroom level as well as the school, in general. The community-control SBM involves parents and the school community in decision making. At the same time, in the balanced-control, SBM autonomy is shared between the school principal, teachers, parents, and school community.

The impact of SBM implementation has shown positive outcomes in various aspects of the school including student attendance, academic achievement and school management (Arar \& Nasra, 2018; Bandur, 2012; Barrera-osorio et al., 2009; Caldwell, 2005; Grauwe, 2005; World Bank, 2013). For example, SBM in the Philippines has resulted in improved school performance within three years (2006-2009) of implementation (World Bank, 2013) while in Indonesia, a significantly positive effect on student learning outcomes since it was started implemented in 2002 (Chen, 2019). These affirmative results have further sparked interests among educators and practitioners, which led to SBM practices to be adopted by more countries. In line with this global education reform, Malaysia 
has implemented SBM through the Education Development Master Plan (EDMP) 2006-2010 by introducing autonomous-cluster schools, which has then expanded this strategy to all schools, based on the Malaysian Education Blueprint (MEB) 2013-2025.

Hussein (2014) emphasized four reasons the importance of SBM implementation in Malaysia. First, SBM strengthens the development and transformational role of the school in the education transformation process; second, SBM engenders local level initiatives with sustainable locally developed programs for lasting transformation effects. Third, SBM enhances local leadership capabilities in terms of management experience and problem-solving, instead of heavily relying on directives from the top; and fourth, SBM recognizes the professional role of school heads and teachers as key players, and the community as stakeholders, especially in terms of decisions that affect them. Thus, SBM is an adaptation made to improve the education system that gives the school autonomy of decision-making on administration and management (Varatharaj, 2015).

However, weak relationships between policy-makers and policy-executors, as well as inefficiencies in centralized and bureaucratic education systems has led to the failure in providing a sustainable education system for students (Ismail \& Abdullah, 2011; Barrera-osorio et al., 2009). Although SBM has been introduced and implemented for more than a decade in Malaysia, it is found that research on SBM in Malaysia is still scarce and have minimal interest among social science researchers when compared to other countries. As an example, even though the Philippines and Malaysia have begun implementing SBM in the same year, in 2006, researchers in the Philippines are more interested in investigating and exploring SBM than researchers in Malaysia. This situation is further confirmed based on the number of evaluation instruments on SBM (Martin, 2019; Tapayan, Ebio, \& Bentor, 2016) and the empirical review report on SBM by the World Bank (2013). As a result of this, details of the implementation and success of SBM in Malaysia are still unclear. Hence, the need to conduct a review of existing studies to collect information on SBM within a decade of implementation in Malaysia is further emphasized.

\section{Objectives}

The purpose of this study was to collect and analyse previous studies on SBM practice in Malaysia to obtain an overview of the current form of management. The objective of this study was to investigate the extent, issues, and challenges of SBM implementation in Malaysia. Within this review, the researcher had used Barrera-osorio et al. (2009) as an indicator of comparison on the level of participation and execution as the study of SBM by them was extensively done worldwide between the 1970s and 2008. Two figures from these authors are used as a comparison to show Malaysia's position in SBM ; the classification of SBM in various countries (fig 2) and autonomyparticipation nexus (fig 3). There were four research questions in this review, (1) How was SBM implemented in Malaysia? (2) What was the classification level of the strength in the implementation of SBM in Malaysia? and (3) To what extent were principals, teachers, parents, and school communities involved in SBM in Malaysia? (4) What are the issues and challenges faced in schools related to SBM? 
INTERNATIONAL JOURNAL OF ACADEMIC RESEARCH IN BUSINESS AND SOCIAL SCIENCES Vol. 10, No. 9, 2020, E-ISSN: 2222-6990 @ 2020 HRMARS

\section{Methods}

To address the research questions, a systematic literature review was performed using fourphase in Preferred Reporting Items for Systematic Reviews and Meta-analyses (PRISMA) (Moher, Liberati, Tetzlaff, Altman, \& The PRISMA Group, 2009) as shown in fig. 1. The research process began with identification phase; online searches using databases such as SCOPUS, SAGE, Science Direct, EBSCOHOST, and Google Scholar with the help of Open Athens. Keywords in Malay and English such as School-Based Management, SBM, Cluster School, Autonomous School, School Autonomy, Teachers Autonomy, Decision Making School, and Shared Decision Making were used to search for relevant studies. In addition to searching for indexed journal articles, conference proceedings, unpublished Ph.Ds. theses, books, and government documents were also considered. There were, however, a limited number of past studies on SBM in Malaysia. As such, several articles and books related to SBM from other countries that comply with the research criteria were also considered. A total of 415 studies were found through database searching and another 4 studies from other sources. 19 duplicate articles removed, thus 400 studies undergo next phase. In screening phase, the scope of the search was narrowed down to several criteria; articles of related studies had been published from 2010 to present, available in the Open Access category and the context of these past studies was Malaysia. A total 387 studies excluded after screening process and only 13 studies were assessed in third phase, eligibility using PRISMA checklist. Finally, 10 studies included and independently summerized in relation to their scope, methods, samples, location and type of school. 
INTERNATIONAL JOURNAL OF ACADEMIC RESEARCH IN BUSINESS AND SOCIAL SCIENCES Vol. 10, No. 9, 2020, E-ISSN: 2222-6990 @ 2020 HRMARS

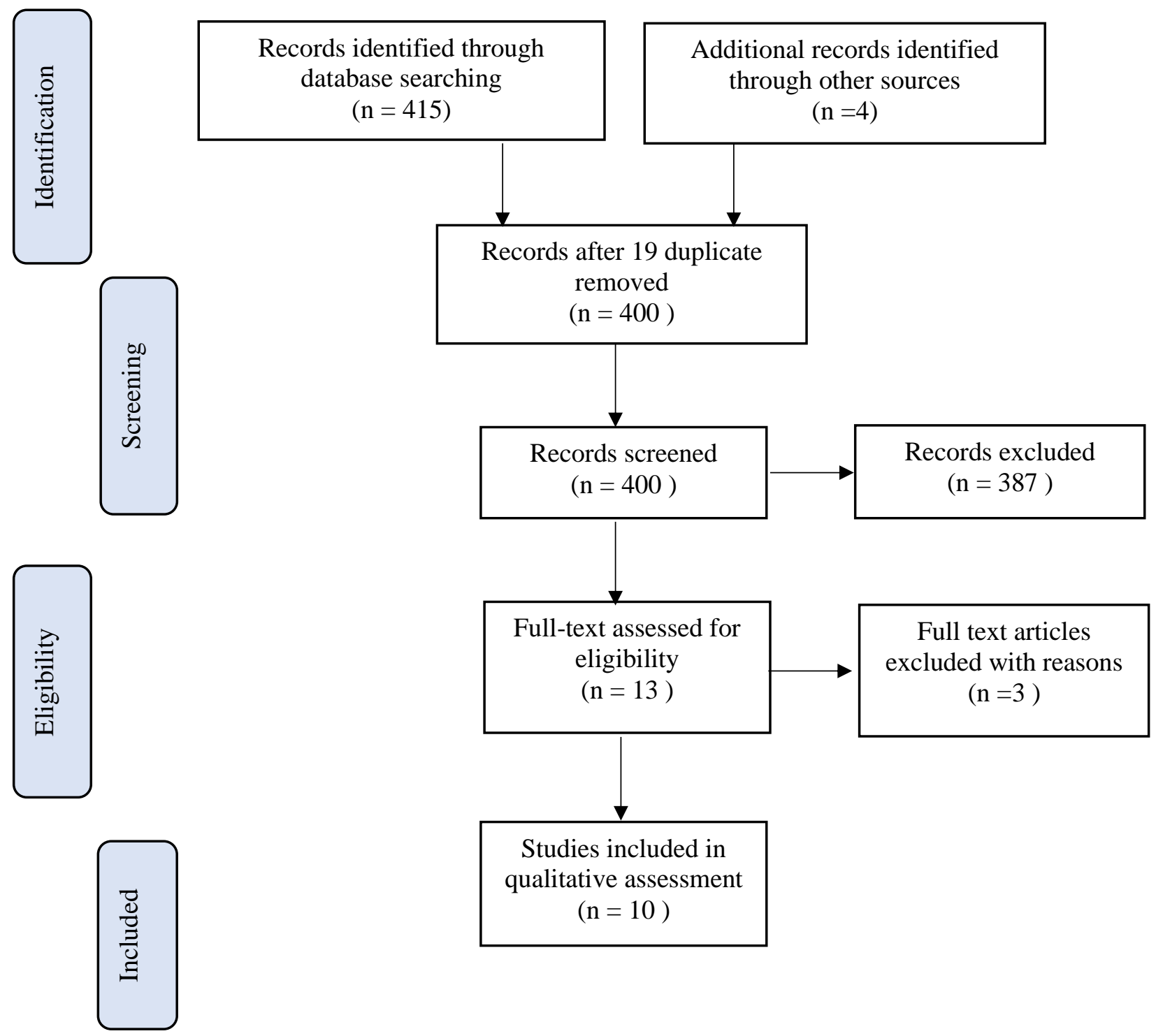

Fig. 1 PRISMA flowchart for systematic review on SBM in Malaysia

\section{Findings}

\section{Summaries of Previous Study}

10 studies included in this study (Ismail \& Abdullah, 2014; Mansor \& Suliman, 2018; Bhattacharyya, 2019; Jeyasushma, Chua, Siaw, \& Kazi, 2017; Hashim, 2017; Suseela \& Faizah, 2011; Tan, 2018; Thilagavathy, 2014; Vally \& Daud, 2015; Varatharaj, 2015) are summarized in table 1 and detailed summaries are provided in appendix. All studies summarized according to scope, methods, samples, location and type of school. SBM related scope reviewed are comparative study between Malaysia cluster school and UK autonomous school (Mansor \& Suliman, 2018), autonomy, accountability and teacher readiness (Ismail \& Abdullah, 2014), SBM challenges (Suseela \& Faizah, 2011), autonomi and assessment (Varatharaj, 2015), leadership competencies and style (Bhattacharyya, 2019), teacher perception, leadership and school culture (Jeyasushma et al., 2017), leadership, organizational knowledge management and instructional innovative behaviour (Hashim, 2017), internal school factor, commitment and work quality (Tan, 2018), SBM implementation and 
INTERNATIONAL JOURNAL OF ACADEMIC RESEARCH IN BUSINESS AND SOCIAL SCIENCES Vol. 10, No. 9, 2020, E-ISSN: 2222-6990 @ 2020 HRMARS

principal readiness (Vally \& Daud, 2015) and leadership capacity, learning organization and commitment (Thilagavathy, 2014).

As for method or approach, 6 studies are using mixed-methods (Mansor \& Suliman, 2018; Ismail \& Abdullah, 2014; Varatharaj, 2015; Hashim, 2017; Tan, 2018; Thilagavathy, 2014), 2 quantitative approach (Jeyasushma et. al,2017; Vally \& Daud, 2015) and 2 qualitative approach (Bhattacharyya, 2019; Suseela \& Faizah, 2011) and sample involve only principal and teachers. Based on column type of school, 5 studies done in cluster school (Mansor \& Suliman, 2018; Bhattacharyya, 2019; Jeyasushma et. al, 2017; Suseela \& Faizah, 2011; Varatharaj, 2015), 3 studies in high performing school (Hashim, 2017; Tan, 2018; Thilagavathy, 2014), 1 studies combination cluster school and high performing school (Ismail \& Abdullah, 2014) and 1 in daily national secondary school (Vally\& Daud, 2015). In term of locations, all studies conducted in peninsular Malaysia mostly in north area state; Perak, Kedah, Perlis, Pulau Pinang with another from centre peninsular; Selangor and Kuala Lumpur.

Several limitations found in the past studies include the types of schools where the studies were carried out, the location, the sample, and the scope of these studies. Most studies focus only on distinctive clusters and autonomous schools. Research on SBM practices on regular daily schools has yet to be done. This limited study is likely to be caused by the fact that SBM started with cluster schools and only extended to regular daily schools a few years later. Comparative studies in SBM on different types of schools such as a public school and a vernacular school should be done to identify the strengths and weaknesses of the implementation. Limitations in terms of location are divided into two - urban and state. Studies of SBM in the urban and rural areas should also consider the differences in access to education that the influence of SBM practices in schools.

Besides, SBM-related studies are found to only involve participants from the northern part of peninsular Malaysia and none on Sabah and Sarawak. Cultural and lifestyle differences may also influence school administration practices. The next limitation is the type of respondent. Previous studies mainly focused only on the teachers and principals as respondents. Studies on the involvement of PTA and community in SBM in Malaysia have yet to be carried out. This study is necessary because SBM aims to increase the participation of parents and communities in the school management to improve the quality of education in schools. The last aspect identified is the scope of the study. The scope of the existing SBM-related research is minimal. It needs to be expanded to include organizational elements, commitment, leadership style, student achievement, school performance, and the impact of SBM practice on MEB 2013-2025. 
INTERNATIONAL JOURNAL OF ACADEMIC RESEARCH IN BUSINESS AND SOCIAL SCIENCES

Vol. 10, No. 9, 2020, E-ISSN: 2222-6990 @ 2020 HRMARS

\begin{tabular}{|c|c|c|c|c|c|c|}
\hline No. & Authors & Scope & Methods & Sample & Location & $\begin{array}{l}\text { Type } \\
\text { school }\end{array}$ \\
\hline 1. & $\begin{array}{l}\text { Ismail } \\
\text { Abdullah } \\
(2014)\end{array}$ & $\begin{array}{l}\text { Autonomy, } \\
\text { accountability } \\
\& \quad \text { teacher } \\
\text { readiness }\end{array}$ & $\begin{array}{l}\text { Mixed- } \\
\text { method }\end{array}$ & $\begin{array}{l}\text { Teachers and } \\
\text { school } \\
\text { administrator }\end{array}$ & $\begin{array}{l}\text { North } \\
\text { Peninsular, } \\
\text { Malaysia }\end{array}$ & $\begin{array}{l}\text { Cluster } \\
\text { School \& } \\
\text { High } \\
\text { Performance } \\
\text { school }\end{array}$ \\
\hline 2. & $\begin{array}{l}\text { Mansor } \\
\text { Suliman } \\
(2018)\end{array}$ & $\begin{array}{l}\text { Comparing } \\
\text { Malaysia } \\
\text { Cluster School } \\
\& \quad \text { UK } \\
\text { Autonomous } \\
\text { school }\end{array}$ & $\begin{array}{l}\text { Mixed- } \\
\text { methods }\end{array}$ & $\begin{array}{l}\text { School } \\
\text { principal }\end{array}$ & $\begin{array}{l}\text { Peninsular, } \\
\text { Malaysia }\end{array}$ & $\begin{array}{l}\text { Cluster } \\
\text { School }\end{array}$ \\
\hline 3. & $\begin{array}{l}\text { Bhattacharyya } \\
\text { (2019) }\end{array}$ & $\begin{array}{l}\text { Leadership } \\
\text { competencies \& } \\
\text { style }\end{array}$ & Qualitative & $\begin{array}{l}\text { School } \\
\text { principal }\end{array}$ & $\begin{array}{l}\text { Perak, } \\
\text { Malaysia }\end{array}$ & $\begin{array}{l}\text { Cluster } \\
\text { School }\end{array}$ \\
\hline 4. & $\begin{array}{l}\text { Jeyasushma, } \\
\text { Chua, Siaw, \& } \\
\text { Kazi (2017) }\end{array}$ & $\begin{array}{l}\text { Teacher } \\
\text { perception, } \\
\text { leadership and } \\
\text { school culture }\end{array}$ & Quantitative & Teachers & $\begin{array}{l}\text { Selangor, } \\
\text { Malaysia }\end{array}$ & $\begin{array}{l}\text { Cluster } \\
\text { school }\end{array}$ \\
\hline 5. & Hashim (2017) & $\begin{array}{l}\text { Leadership, } \\
\text { organizational } \\
\text { knowledge } \\
\text { management, } \\
\text { instructional } \\
\text { innovative } \\
\text { behaviour }\end{array}$ & $\begin{array}{l}\text { Mixed- } \\
\text { methods }\end{array}$ & Teachers & $\begin{array}{l}\text { Perlis, } \\
\text { Kedah, } \\
\text { Perak \& } \\
\text { Pulau } \\
\text { Pinang }\end{array}$ & $\begin{array}{l}\text { High } \\
\text { performance } \\
\text { school }\end{array}$ \\
\hline 6. & $\begin{array}{l}\text { Suseela \& } \\
\text { Faizah (2011) }\end{array}$ & SBM chalanges & Qualitative & $\begin{array}{l}\text { Principal \& } \\
\text { teachers }\end{array}$ & $\begin{array}{l}\text { Peninsular, } \\
\text { Malaysia }\end{array}$ & $\begin{array}{l}\text { Cluster } \\
\text { School }\end{array}$ \\
\hline 7. & Tan (2018) & $\begin{array}{l}\text { Internal school } \\
\text { factor, } \\
\text { commitment \& } \\
\text { work quality } \\
\end{array}$ & $\begin{array}{l}\text { Mixed- } \\
\text { methods }\end{array}$ & Teachers & $\begin{array}{l}\text { North } \\
\text { peninsular, } \\
\text { Malaysia }\end{array}$ & $\begin{array}{l}\text { High } \\
\text { performance } \\
\text { schools }\end{array}$ \\
\hline 8. & $\begin{array}{l}\text { Thilagavathy } \\
\text { (2014) }\end{array}$ & $\begin{array}{l}\text { Leadership } \\
\text { capacity, } \\
\text { learning } \\
\text { organization, } \\
\text { commitment }\end{array}$ & $\begin{array}{l}\text { Mixed- } \\
\text { methods }\end{array}$ & Teachers & $\begin{array}{l}\text { North } \\
\text { peninsular, } \\
\text { Malaysia }\end{array}$ & $\begin{array}{l}\text { High } \\
\text { performance } \\
\text { schools }\end{array}$ \\
\hline 9. & $\begin{array}{l}\text { Vally \& Daud } \\
\text { (2015) }\end{array}$ & $\begin{array}{l}\text { SBM } \\
\text { Implementation } \\
\& \quad \text { principal } \\
\text { readiness }\end{array}$ & Quantitative & Principals & $\begin{array}{l}\text { Kuala } \\
\text { Lumpur, } \\
\text { Malaysia }\end{array}$ & $\begin{array}{l}\text { National } \\
\text { Secondary } \\
\text { school }\end{array}$ \\
\hline
\end{tabular}


INTERNATIONAL JOURNAL OF ACADEMIC RESEARCH IN BUSINESS AND SOCIAL SCIENCES Vol. 10, No. 9, 2020, E-ISSN: 2222-6990 @ 2020 HRMARS

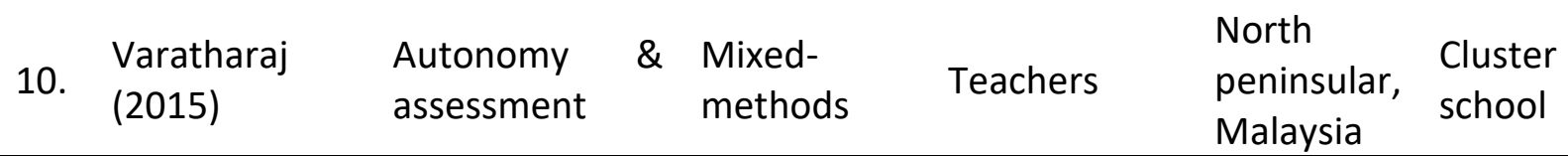

Table 1 Summaries of previous studies

\section{SBM Implementations in Malaysia}

School-Based Management (SBM) was first practiced in Malaysia over two decades ago (Mansor \& Suliman, 2018) through the establishment of cluster schools, an effort that was outlined in the Education Development Master Plan (EDMP) 2006-2010 (Ismail \& Abdullah, 2011). The selection criteria to be a cluster school include being one of the best performing schools based on the average achievement of at least three consecutive public examinations, a high-grade school average as well as the number of students with $A$, and having a history of excellence in certain subjects (Kementerian Pendidikan Malaysia, 2006). Schools that have been awarded special awards and achieved regional, national, and overseas co-curricular achievements were also considered. For example, national innovation awards, robotic, arts, and dance competitions organized not only by the Ministry of Education but other government agencies and private sectors too. Principals in cluster schools were given the autonomy to manage five areas within the school, namely resource management, school funds, student recruitment, teaching, and learning as well as examinations and assessments (Suseela \& Faizah, 2011). According to Ismail and Abdullah (2014), the creation of autonomous schools was based on a decentralized process involving school empowerment through the provision of independent leadership. This form of autonomy meant that schools must adhere to specific standards despite being given freedom in school-based management.

The transformation in the education policy from EDMP 2006-2010 to the MEB 2013-2025 saw the concept of school-based management was not only confined to cluster schools but had extended to all types of schools in the country. The extent of autonomous power given by the Ministry of Education Malaysia was observed in the $6^{\text {th }}$ core point in MEB 2013-2025 where the State Education Department (JPN), District Education Office (PPD), and schools were empowered to provide custombased solutions to accelerate school performance. Various improvement through district-led systematic programs in each state and school-based and autonomous management were carried out to enable schools to meet the minimum performance criteria (Kementerian Pendidikan Malaysia, 2013). It was reported in the MEB 2013-2025 Annual Report that autonomy was also given to schools in terms of the management and intervention of literacy and numeracy as well as the flexibility of principals and teachers in managing school finances (Kementerian Pendidikan Malaysia, 2018).

The implementation of School-Based Assessment (SBA) began in 2010 (Raman \& Yamat, 2014) and is still ongoing, with several phases of improvement throughout this past decade. By the end of 2019, school autonomy had extended entirely to full classroom assessment by eliminating mid-year and final year examinations of level one (year 1, 2 \& 3) at all government primary schools. This elimination means that there would be no more exams for students at level one, having it replaced with year-round formative assessments to see student progress and teaching outcomes. Teachers were given full autonomy in planning, implementing, evaluating, assessing, and guiding students in this form of classroom assessment. However, even though teachers were likely to have complete autonomy in the classroom assessment, there were still guidelines that teachers needed to follow. 
INTERNATIONAL JOURNAL OF ACADEMIC RESEARCH IN BUSINESS AND SOCIAL SCIENCES Vol. 10, No. 9, 2020, E-ISSN: 2222-6990 @ 2020 HRMARS

This type of autonomy is known as guided autonomy (Ismail \& Abdullah, 2014), which undoubtedly demonstrated that the practice of SBM in Malaysia is still somewhat, controlled (Vally \& Daud, 2015).

Based on previous studies, the type of SBM model that has been implemented in Malaysia was a combination of two models, which are administrative-control SBM and professional-control SBM. Both models were found to be used interchangeably, depending on the areas of school management. For example, decision-making in teacher assessment was entirely controlled by the school leader while the teachers were in-charge of student assessment.

\section{Level of SBM Implementation}

The level of autonomy by the school administrator can further define the level of SBM, staff, and school community which consisted of parents and students. Barrera-osorio et al. (2009) have divided the SBM level into five levels, which are weak, moderate, somewhat strong, strong, and very strong. The weak level describes the limited autonomy in school affairs, restrictive to only school planning and instruction. The moderate level shows that a school council has been established but serves only as an advisory role. The level of somewhat strong illustrates the school council having the autonomy to hire and fire teachers, as well as principals, set the school curriculum, and control school funding. At the strong level, control of substantial resources and parental and community control of the school was added to the description of the previous level. Finally, at a very strong level, parents and other stakeholders have the autonomy to create a school.

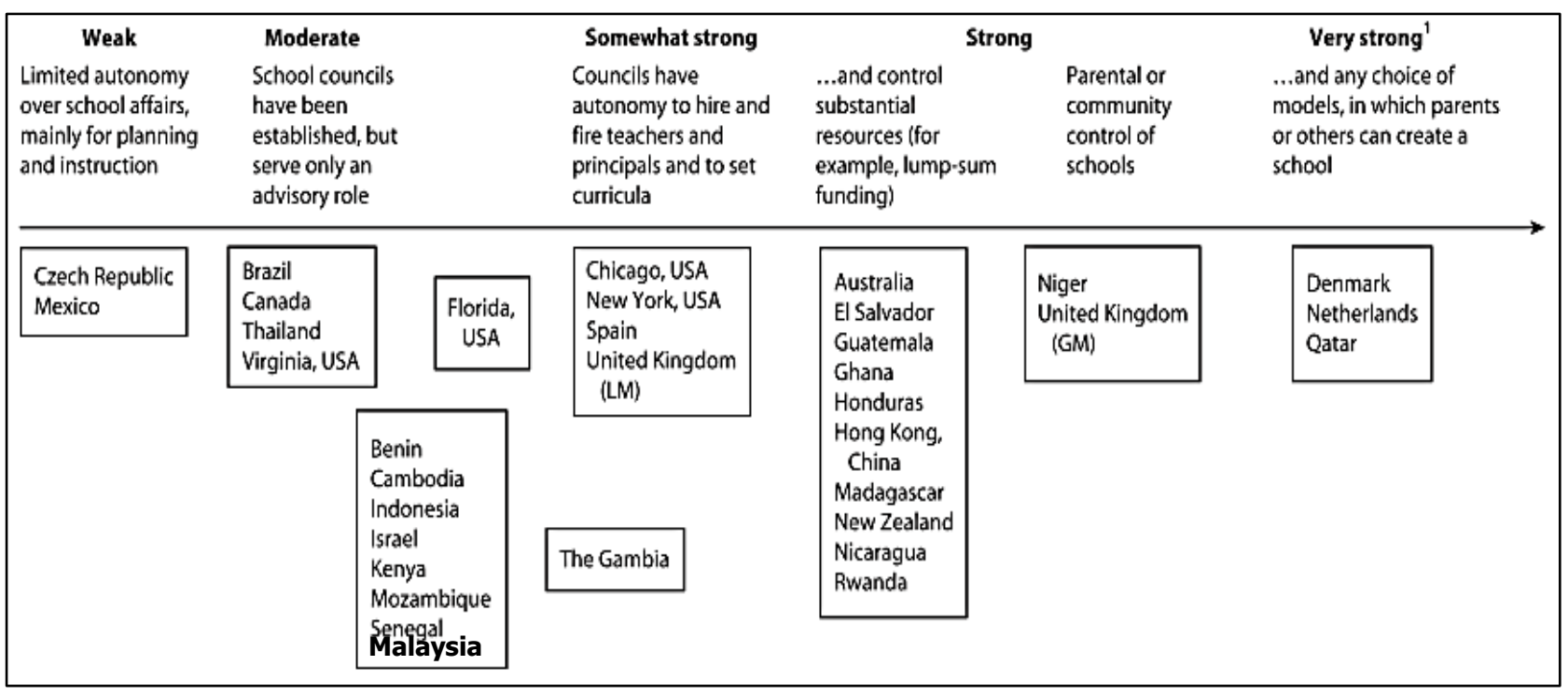

Fig. 2 Malaysia Position in the Classification of School-Based Management Reform in Various Economy

Adapted from: Barrera-osorio, Fasih, Patrinos, \& Santibanez, (2009). Decentralized Decision-Making in Schools: The Theory and Evidence on School-Based Management. Washington D.C: World Bank Publications. https://openkonwledge.worldbank.org/handle/10986/2632 Licence: Creative Commons Attribution Licence (CC BY 3.0 IGO)

*This is an adaptation of original work by Barrera-osorio, Fasih, Patrinos, \& Santibanez, (2009). 
INTERNATIONAL JOURNAL OF ACADEMIC RESEARCH IN BUSINESS AND SOCIAL SCIENCES Vol. 10, No. 9, 2020, E-ISSN: 2222-6990 @ 2020 HRMARS

Responsibility for the views and opinions expressed in the adaptation rest solely with the author and are not endorsed by any member institution of the World Bank Group.

Fig 2 showed the classification of SBM in various countries since the 1980s until 2009 by Barrera-osorio et al. (2009). Studies on SBM in Malaysia had only started after the EDMP 2006-2010 was outlined. The result of a decade-long literature review on the implementation of SBM in Malaysia was found to be at a moderate level. This finding was based on the entities of the school managing system, which involved mainly the school principal, teachers, and Parent-Teacher Association (PTA). Government schools in Malaysia have yet to have the authority in hiring and firing teachers as described in the somewhat strong level. Thus, the level of SBM concluded for Malaysia was at a moderate level, alongside other Southeast Asian countries such as Indonesia and Cambodia, as showed in fig. 2.

The individuals involved as participants of autonomy such as the school principal, teachers, parents, and school community were shown in fig.3. Fig. 3 also showed the position of school principals and teachers in Malaysia compared to other countries. The results from previous studies found that teacher autonomy was at a moderate level in terms of teaching and learning (Ali, Abdullah, \& Mohammad, 2019) as well as in student assessment (Varatharaj, 2015). Additionally, Ismail and Abdullah (2014) found that the level of autonomy among teachers was higher at schools in an urban area than in rural areas. This difference was also found to have occurred not only in Malaysia but also in other Southeast-Asian countries such as Vietnam, Thailand, and Indonesia (Shoraku, 2009). This finding showed that equality of access to education, especially the availability and access to facilities affected teacher's autonomy. Although the level of autonomy was at a moderate level, a comparative study found the autonomy level of autonomous schools in the United Kingdom (UK) was way higher than the cluster schools in Malaysia (Mansor \& Suliman, 2018). There are, at present, limited studies regarding PTA autonomy or decision making in schools under SBM in Malaysia.

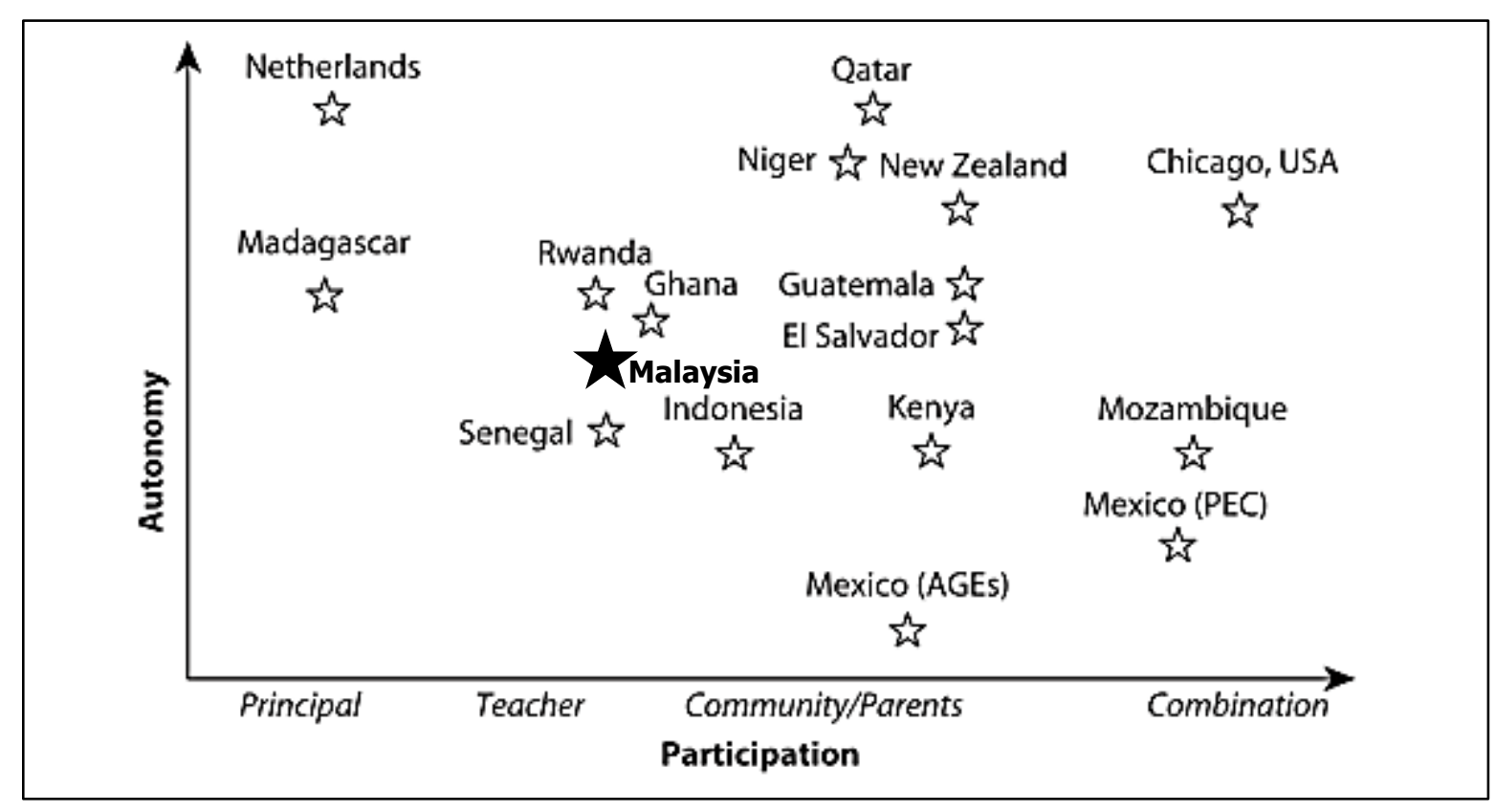


INTERNATIONAL JOURNAL OF ACADEMIC RESEARCH IN BUSINESS AND SOCIAL SCIENCES Vol. 10, No. 9, 2020, E-ISSN: 2222-6990 @ 2020 HRMARS

Fig. 3 Autonomy-Participation Nexus with the selected country (Malaysia plotted)

Adapted from: Barrera-osorio, Fasih, Patrinos, \& Santibanez (2009). Decentralized Decision-Making in Schools: The Theory and Evidence on School-Based Management. Washington D.C: World Bank Publications. https://openkonwledge.worldbank.org/handle/10986/2632 Licence: Creative Commons Attribution Licence (CC BY 3.0 IGO)

*This is an adaptation of original work by Barrera-osorio, Fasih, Patrinos, \& Santibanez (2009). Responsibility for the views and opinions expressed in the adaptation rest solely with the author and are not endorsed by any member institution of the World Bank Group.

\section{Issues and Challenges}

Results from the previous studies have identified two critical issues on the implementation of SBM in Malaysia; the role of a school leader and teacher competency. As a school leader, principal or headmaster, plays a significant role in ensuring education policies are implemented accordingly. Leadership capacity and quality among the principal and headmaster are an important element in SBM practice (Caldwell, 2005; Harris \& Lambert, 2003; World Bank, 2013). Hussein (2014) has stressed that there are several aspects in terms of leadership that are ideal in fulfilling the autonomous role given such as the capacity of the principal or headmaster, the ability and professional knowledge to handle education developmental, and transformational issues at the local context. The main challenge in managing a school organization is the leadership and capability of the principal. Poor leadership skills would result in poor quality school achievement. The principals must be willing to bear huge responsibility in managing the school based on the SBM system because not everyone is willing to take on this enormous task.

In SBM, the more effective the principal is in their role, the more effective the implementation of the school mission and vision; which leads to greater efficiency of human resource management (Shoma et al., 2015). Mansor and Suliman (2018) have both emphasized the competency of a principal or headmaster as one of the factors that can affect the effectiveness of the cluster school. Ali et al. (2019) have suggested that school authorities, mainly the principals or headmasters, should explore various activities to enhance their leadership abilities and autonomy that are relevant to the management systems and educational aspirations of the 21st century. Therefore, it can be concluded that the principals and headmasters need to be empowered to increase the level of efficiency in their leadership qualities to govern school institutions and achieve the goal of SBM, which is to improve the quality of education.

Besides the role of school leaders, teacher competency is also a major contributing factor to the successful implementation of a policy. Ali et al. (2019) have found significant influence between decision-making and personal competency dimension of teacher empowerment and teacher autonomy in general as well as specifically in the curriculum aspects. Teachers, as autonomous individuals, need to take proactive steps in optimizing the freedom in decision-making and autonomy to overcome education-related problems (Varatharaj, 2015). Ismail and Abdullah (2014) have concluded that the autonomy and accountability aspects being practiced in Malaysian autonomous schools will demand a better-prepared teacher to serve as a professional individual in school. Teacher involvement in decision making can also increase the motivation to excel in their teaching practices while increasing the level of efficiency and effectiveness in teaching. 
INTERNATIONAL JOURNAL OF ACADEMIC RESEARCH IN BUSINESS AND SOCIAL SCIENCES Vol. 10, No. 9, 2020, E-ISSN: 2222-6990 @ 2020 HRMARS

However, there are still concerns among stakeholders about the accountability of teachers for possible abuse or misuse of the autonomy given (Md. Ali \& Arsaythamby, 2017). The concerns raised revolve around the possibilities of some teachers being unable to perform or cope with the increased level of autonomy which further proves the importance placed on and the need for teachers to be physically and mentally prepared to be challenged when implementing any new policy. Another issue raised by Hussein (2014) was over the expectation of teacher capabilities in achieving the objectives of student aspiration in terms of knowledge, thinking skills, leadership skills, bilingual skills, ethics and spirituality, and national identity. Teachers are expected to be versatile, well prepared, and willing to go the extra mile in staying committed to the school.

Moreover, misunderstandings among teachers about the changes in the education system and the lack of involvement among the local school community in school management can contribute to the effectiveness in the implementation of SBM. The shortcomings when implementing SBM can be due to inadequate understanding of SBM implementation as well as minimal parental and community involvement as information is given in chunks or stages (Bandur, 2017; Syahruddin, 2014; Varatharaj, 2015).

\section{Discussions}

Further improvements are expected to result in an improved understanding of SBM, which can lead to enhanced school autonomy. Hence, the researcher has proposed five areas in schools where the implementation of SBM can be improved, which are the SBM instrument, the state-district roles in schools, Parent-Teachers Association (PTA) leader capacity and teacher empowerment. First, assessment instruments on SBM should be developed by the Ministry of Education (MoE) to identify aspects that can and cannot be implemented in all schools. The instrument should also focus on evaluating the involvement of all stakeholders in decision-making at the respective schools and samples of SBM best practices. For example, the Philippines have evaluated and distinguished the implementation of SBM in their country into three levels; standard, progressive, and matured (Tapayan et al., 2016). The results from this instrument will present the effectiveness of SBM throughout Malaysia as part of achieving the educational goals of the country. Based on the instrument result, implementation of SBM can be further reviewed and improved. Currently, the MoE is using the Malaysian Education Quality Standard $2^{\text {nd }}$ Wave (MEQSW2) instrument to evaluate the quality of a school. However, this instrument does not assess any SBM practices in schools. Without proper evaluation, the success of SBM practices cannot be confirmed. It is crucial to understand that unless policies and strategies are being properly implemented and carefully monitored and evaluated regularly in a country, national educational policies will be deemed meaningless in propelling the nation further to be a developed country (UNESCO, 2015).

Second, the roles at the district and state-level should be monitored to prevent misunderstanding and over-guidance in the implementation of education policies. Conflicts often arise whenever a new education policy is announced, especially during a transitional phase. The more intervention by district and state officers, the less teacher autonomy can be carried out in schools (Kim, 2018). Other than monitoring policy implementation, empowerment in school leaders and teachers, as well as identifying problematic teachers for further action should be focused at the district and state levels. Courses and workshops related to SBM that involve the school leader, 
INTERNATIONAL JOURNAL OF ACADEMIC RESEARCH IN BUSINESS AND SOCIAL SCIENCES Vol. 10, No. 9, 2020, E-ISSN: 2222-6990 @ 2020 HRMARS

teachers, parent, and community should be organized and promoted at the state and district levels to enhance further their knowledge and motivation in implementing this strategy in schools.

The results from the previous study also show a lack of parental and community involvement in school management. Therefore, the third recommendation is pertaining to the role of the PTA and community, which should not be limited to the collection of contributions or funds and celebrations of festivities. These groups of stakeholders should be involved in determining the direction, mission, and vision of the school. The involvement by the PTA and community is crucial to increase the level of autonomy participation in SBM. This involvement can be done by establishing a School Guiding Council (SGC) in all public schools throughout Malaysia. SGC is a norm in autonomous schools but not in national public schools. Members in the SGC include the principals or the headmasters, PTA committee, and expert teacher(s) who have the knowledge and professionalism to contribute in determining the school vision.

Fourth, the quality of leaders is a critical element in education and needs to be improved. Issues and challenges previously have identified the role of school leaders to be considered for improvement. Leadership capacity and the quality of the principals or headmaster are significant in the success of SBM implementation and practices (Ismail \& Abdullah, 2011; Caldwell, 2005; Harris \& Lambert, 2003). Thus, efficient and enough professional development and support should be given to school principals or headmasters to improve their leadership styles in a way that will help in implementing the SBM (Kaabi, 2015). The school leaders need to undergo training that focuses on SBM practices and be involved in coaching and mentoring sessions with principals from autonomous or cluster schools. In other words, empowering principals or headmasters is a critical step in providing them with the accountability of decision-making in schools.

Lastly, it is essential to understand that empowered leaders empower teachers. Teacher plays a crucial part in any policy implementations. Instilling leadership skills among teachers to enhance confidence and motivation will increase the supportive attitude needed towards SBM implementation (Kaabi, 2015; Shoraku, 2009). In any given policy, teachers are generally considered to be always ready for changes. However, teachers face loads of schoolwork and problems. There are inconsistencies between classroom practices that teachers believe in and prefer to use, with the practices mandated by policy, which are materialized in the form of the external testing system and accountability practice (Skedsmo \& Huber, 2018). However, it is common for administrators and teachers to always carry out all tasks following the established guidelines. Therefore, it is highly recommended to increase the motivation and guidance among teachers in areas such as pedagogy, professional development, accountability, and integrity. The autonomy in decision making among teachers will not be useful if the teachers are not prepared to be more proactive in his or her work. The ability to adapt to changes is a crucial trait among teachers as a part of their professionalism.

\section{Conclusion}

Malaysia still has a long way to go in achieving an advanced education system compared to the other developed countries. After more than a decade of implementation, SBM in Malaysia is at a moderate level based on the participation and the autonomy of principals, teachers, parents, and community. This strategy is implemented using the administrative-control SBM and professional- 
INTERNATIONAL JOURNAL OF ACADEMIC RESEARCH IN BUSINESS AND SOCIAL SCIENCES Vol. 10, No. 9, 2020, E-ISSN: 2222-6990 @ 2020 HRMARS

control SBM models. The role of the school leader and teacher competency are two issues raised in this review which need to be taken into consideration in improving SBM. The researcher has proposed the need of a standard instrument to evaluate SBM, emphasized the role of district and state officer in focusing on the empowerment of school leader and teacher, the PTA involvement, leadership capacity, and teacher empowerment to increase the motivation and guidance in areas such as pedagogy, professional development, accountability, and integrity.

\section{References}

Ali, A. J, Abdullah, A. G. K., \& Mohammad, I. (2019). Amalan Pengupayaan dan Autonomi Guru dalam Pembelajaran dan Pemudahcaraan Abad ke-21. Jurnal Kepimpinan Pendidikan, 6(Januari), 4958. https://doi.org/10.1016/j.tca.2018.07.022

Alyami, R., \& Floyd, A. (2019). Female school leaders' perceptions and experiences of decentralisation and distributed leadership in the tatweer system in Saudi Arabia. Education Sciences, 9(1). https://doi.org/10.3390/educsci9010025

Arar, K., \& Nasra, M. A. (2018). Linking school-based management and school effectiveness: The influence of self-based management, motivation and effectiveness in the Arab education system in Israel. Educational Management Administration and Leadership, 1-19. https://doi.org/10.1177/1741143218775428

Bandur, A. (2012). School-Based Management Developments And Partnership: Evidence from Indonesia. International Journal of Educational Development, 32(2), 316-328. https://doi.org/10.1016/j.ijedudev.2011.05.007

Bandur, A. (2017). Stakeholders' Responses To School-based Management in Indonesia. International Journal of Education Management, Vol.08(0191).

Barasa, T. (2014). Successful Decentralization : The Roles and Challenges of DEOs in Kenya. France: The International Institute for Educational Planning (IIEP).

Barrera-osorio, F., Fasih, T., Patrinos, H. A., \& Santibanez, L. (2009). Decentralized Decision-Making in Schools : The Theory and Evidence on School-Based Management. https://doi.org/10.1596/9780-8313-7969-1

Bhattacharyya, E. (2019). Leadership competencies and leadership style in aspiring cluster schools of excellence. Pertanika Journal of Social Sciences and Humatinies, 27(2), 1111-1129.

Caldwell, B. J. (2005). School-based Management. France: The International Institute for Educational Planning (IIEP).

Chen, D. (2019). School-Based Management, School Decision-Making and Education Outcomes in Indonesian Primary Schools. In School-Based Management, School Decision-Making and Education Outcomes in Indonesian Primary Schools. https://doi.org/10.5040/9781474209731.0002

Grauwe, A. De. (2005). School-based Management ( SBM ): Does It Improve Quality ? Quality, 1-14. Harris, A., \& Lambert, L. (2003). Building Leadership Capacity for School Improvement. In RefineCatch Limited (Ed.), Open University Press - Philadelphia. England: McGraw-Hill Education.

Hashim, N. H. (2017). Kepimpinan Lestari Pengetua, Pengurusan Pengetahuan Organisasi Dan Tingkah Laku Inovatif PengajarannGuru Di Sekolah Menengah Harian Berpencapaian Tinggi Di Utara Semenanjung Malaysia. University Sains Malaysia.

Hussein, A. (2014). Implementation of strategic education policy plan at micro-level contexts: Management and leadership challenges. Malaysian Online Journal of Educational Management. 
INTERNATIONAL JOURNAL OF ACADEMIC RESEARCH IN BUSINESS AND SOCIAL SCIENCES Vol. 10, No. 9, 2020, E-ISSN: 2222-6990 @ 2020 HRMARS

Ismail, A., \& Abdullah, A. G. K. (2011). Konsep Asas Dalam Amalan Desentralisasi Pendidikan. Pulau Pinang: Universiti Sains Malaysia.

Ismail, A., \& Abdullah, A. G. K. (2014b). Amalan Autonomi Dan Akauntabiliti Di Sekolah Berautonomi Dan Impaknya Terhadap Kesediaan Guru. Jurnal Kepimpinan Pendidikan, 3(1), 32-46.

Jeyasushma, V., Chua, Y. P., Siaw, Y. L., \& Kazi, E. H. (2017). Teacher's Perception On The Relationships Between Transformational Leadership And School Culture In Primary Cluster Schools. Malaysian Online Journal Of Educational Management, 5(4), 18-34.

Kaabi, S. A. A. Al. (2015). An Evaluation of the School-Based Management Practices in the New School Model : a Study on Al Ain Schools. United Arab Emirates University.

Kementerian Pendidikan Malaysia. Pelan Induk Pembangunan Pendidikan 2006-2010. , Kementerian Pendidikan Malaysia § (2006).

Kementerian Pendidikan Malaysia. Pelan Pembangunan Pendidikan Malaysia 2013 - 2025 (Pendidikan Prasekolah hingga Lepas Menengah). , (2013).

Kementerian Pendidikan Malaysia. (2018). Laporan Tahunan 2018 : Pelan Pembangunan Pendidikan Malaysia 2013-2025. Putrajaya.

Kim, J. (2018). School accountability and standards-based education reform: The recall of social efficiency movement and scientific management. International Journal of Educational Development, 60(May 2017), 80-87. https://doi.org/10.1016/j.ijedudev.2017.11.003

Leithwood, K., \& Menzies, T. (1998). Form and Effects of School-Based Management : A Review. Educational Policy, 12(3), 325-346.

Mansor, A. N., \& Suliman, A. (2018). The Practice Of School-based Management : Special Reference To Malaysian Clusters Schools And Uk Autonomous Schools. Journal of Adv Research Dynamical \& Control System, Vol. 10(02-Special Issue), pp-1618-1626.

Martin, M. (2019). The implementation of school-based management in public elementary schools. Asian Journal of Assessment in Teaching and Learning, 9(1), 44-56. Retrieved from http://ojs.upsi.edu.my/index.php/AJATeL/article/view/2314\%0Ahttp://files/351/The

Implementation of School-Based Management in Public Elementary Schools_ 2019.pdf\%0Ahttp://files/352/2314.html

Md. Ali, R., \& Arsaythamby, V. (2017). Teachers' Autonomy and Accountability in Assessing Students' Physical Education in School-Based Assessment. In I. H. Amzat \& N. P. Valdez (Eds.), Teacher Empowerment Toward Professional Development and Practices: Perspectives Across Borders (pp. 71-83). https://doi.org/10.1007/978-981-10-4151-8

Moher, D., Liberati, A., Tetzlaff, J., Altman, D., \& The PRISMA Group. (2009). Preferred reporting items for Systematic Reviews and meta-analysis. Plos Med, 6(7). https://doi.org/10.1371/journal.pmed1000097

Moradi, S., Hussin, S. Bin., \& Barzegar, N. (2012). School-Based Management (SBM), Opportunity or Threat (Education systems of Iran). Procedia - Social and Behavioral Sciences, 69(Iceepsy), 21432150. https://doi.org/10.1016/j.sbspro.2012.12.179

Raman, K., \& Yamat, H. (2014). English teachers' voices on the challenges of the School-Based Assessment. Frontiers of Language and Teaching, 5, 66-74.

Shoraku, A. (2009). Educational movement toward school-based management in East Asia: Cambodia, Indonesia and Thailand. Background Paper for EFA Global Monitoring Report. Retrieved from http://unesco.atlasproject.eu/unesco/file/d0b7b767-9e2b-4e2a-bff0783b6ae6f15b/c8c7fe00-c770-11e1-9b21-0800200c9a66/178720e.pdf 
INTERNATIONAL JOURNAL OF ACADEMIC RESEARCH IN BUSINESS AND SOCIAL SCIENCES Vol. 10, No. 9, 2020, E-ISSN: 2222-6990 @ 2020 HRMARS

Skedsmo, G., \& Huber, S. G. (2018). Teacher evaluation: the need for valid measures and increased teacher involvement. Educational Assessment, Evaluation and Accountability, 30(1), 1-5. https://doi.org/10.1007/s11092-018-9273-9

Suseela, M., \& Faizah, S. (2011). Challenges in school-based management : Case of a ' cluster school ' in Malaysia. Procedia - Social and Behavioral Sciences, 15, 1488-1492. https://doi.org/10.1016/j.sbspro.2011.03.316

Syahruddin. (2014). Pengurusan Berasaskan Sekolah Menengah Pertama Bandar Pare-pare Provinsi Sulawesi Selatan Indonesia. Universiti Teknologi Malaysia.

Tan, L. K. (2018). Faktor Dalaman Sekolah Dan Komitmen Guru Terhadap Organisasi : Pengaruh Pengantara Kualiti Kehidupan Kerja Guru Di SBT dan SBBT. University Sains Malaysia.

Tansiri, I. Y., \& Bong, Y. J. (2018). The Analysis of School-Based Management (SBM) Implementation to the Educational Quality Service of State Junior High School. Advances in Social Science, Education and Humanities Research (ASSEHR), 258(Icream 2018), 424-426. https://doi.org/10.2991/icream-18.2019.89

Tapayan, H. N., Ebio, F. M., \& Bentor, C. T. S. (2016). Impact of School-Based Management Level of Practices Among Secondary School Implementing Units on the K To 12 Program. 5(5), 558-574.

Thilagavathy, A. (2014). Pengaruh Moderasi kapasiti Kepimpinan Diri Guru Terhadap Hubungan Antara Organisasi Pembelajaran Dengan Komitmen Kualiti Pengajaran Guru Di Sekolah Berprestasi Tinggi Di Malaysia. University Sains Malaysia.

UNESCO. (2015). Malaysia National Education for All Review Report. World Education Forum, 1-128. Vally, G. V. S., \& Daud, K. (2015). The Implementation of School Based Management Policy: An Exploration. Procedia - Social and Behavioral Sciences, 172, 693-700. https://doi.org/10.1016/j.sbspro.2015.01.421

Varatharaj, R. (2015). Autonomi Guru Dan Amalan Pentaksiran Dalam Pengajaran Dan Pembelajaran Kurikulum Standard Sekolah Rendah (KSSR) Di Sekolah Kluster. University Sains Malaysia.

Varatharaj, R., Abdullah, A. G. K., \& Ismail, A. (2015). The Effect of Teacher Autonomy on Assessment Practices among Malaysian Cluster School Teachers. International Journal of Asian Social Science, 5(1), 31-36. https://doi.org/10.18488/journal.1/2015.5.1/1.1.31.36

World Bank. (2013). Republic of the Philippines Basic Education Public Expenditure Review Phase II School Based Management in the Philippines : An Empirical Investigation. Washington D.C. 